\title{
EFFECT OF SIZE OF INTESTINAL DIVERSIONS IN OBESE PATIENTS WITH METABOLIC SYNDROME SUBMITTED TO GASTRIC BYPASS
}

\author{
Efeito da dimensão das derivações intestinais em obesos com síndrome metabólica submetidos ao bypass gástrico
}

Rafael Jacques RAMOS ${ }^{1,2}$, Cláudio Corá MOTTIN ${ }^{1,2}$, Letícia Biscaino ALVES ${ }^{1,2}$, Daniela BENZANO ${ }^{1}$, Alexandre Vontobel PADOIN ${ }^{1,2}$

From the ${ }^{1}$ Centro da Obesidade e Síndrome Metabólica, Hospital São Lucas, Pontifícia Universidade Católica do Rio Grande do SulPUCRS; and 2Programa de Pós Graduação em Medicina e Ciências da Saúde da PUCRS ('Obesity and Metabolic Syndrome Center Hospital São Lucas, Pontifical Catholic University of Rio Grande do Sul - PUCRS; and 'Program of Postgraduate Medicine and Health Sciences at PUCRS), Porto Alegre, RS, Brasil.

HEADINGS - Bariatric surgery. Morbid obesity. Type 2 diabetes mellitus. Y-de-Roux Gastric Derivation. Lipid disorder. Metabolic syndrome.
ABSTRACT - Background: There is no consensus on the ideal size of intestinal loops in gastric bypass of bariatric surgeries. Aim: To evaluate the metabolic outcome of patients submitted to gastric bypass with alimentary and biliopancreatic loops of different sizes. Methods: Was conducted a retrospective cohort study in diabetic obese patients $\left(B M I \geq 35 \mathrm{~kg} / \mathrm{m}^{2}\right)$ with metabolic syndrome submitted to gastric bypass. The patients were divided into three groups according to the size of the intestinal loop: group 1, biliopancreatic limb $50 \mathrm{~cm}$ length and alimentary limb $100 \mathrm{~cm}$ length; group 2, biliopancreatic limb $50 \mathrm{~cm}$ length and alimentary limb $150 \mathrm{~cm}$ length; and group 3, biliopancreatic limb $100 \mathrm{~cm}$ length and alimentary limb 150 $\mathrm{cm}$ length. The effect of gastric bypass with different sizes of intestinal loops in relation to the parameters that define metabolic syndrome was determined. Results: Sixty-three patients were evaluated, and they had a mean age of $44.7 \pm 9.4$ years. All were diabetics, with $62(98.4 \%)$ being hypertensive and 51 (82.2\%) dyslipidemic. The three groups were homogeneous in relation to the variables. In 24 months, there was a remission of systemic arterial hypertension in $65 \%$ of patients in group 1, 62.5\% in group 2 and $68.4 \%$ in group 3 . Remission of diabetes occurred in $85 \%$ of patients in group 1,83\% in group 2 and $84 \%$ in group 3 . There was no statistical difference in \%LEW between the groups, and waist measurements decreased in a homogeneous way in all groups. The size of loops also had no influence on the improvement in dyslipidemia. Conclusion: Variation in size of intestinal loops does not appear to influence improvement in metabolic syndrome in this group of patients.

\section{Correspondence:}

Rafael Jacques Ramos

E-mail: rjramos@terra.com.br

Financial source: Conselho Nacional de Desenvolvimento Científico e Tecnológico (CNPq) e FINEP research grant "Com-Avabar - Avaliação da Cirurgia Bariátrica no Brasil"

Conflicts of interest: none

Received for publication: 12/01/2016 Accepted for publication: 14/04/2016

DESCRITORES: Cirurgia bariátrica Obesidade mórbida. Diabete melito tipo 2. Derivação gástrica em Y-de-Roux. Dislipidemia. Síndrome metabólica.
RESUMO - Racional: Não há consenso sobre o tamanho ideal das alças intestinais no bypass gástrico em Y-de-Roux em cirurgias bariátricas. Objetivo: Avaliar os desfechos metabólicos de pacientes submetidos ao bypass gástrico com alça intestinal alimentar e biliopancreática de tamanhos diferentes. Métodos: Realizou-se coorte retrospectiva em pacientes obesos $\left(\mathrm{IMC} \geq 35 \mathrm{~kg} / \mathrm{m}^{2}\right)$ diabéticos com síndrome metabólica submetidos ao bypass gástrico em Y-de-Roux. Foram divididos em três grupos conforme a dimensão das alças intestinais: grupo 1, alça biliopancreática de $50 \mathrm{~cm}$ e alça alimentar de $100 \mathrm{~cm}$; grupo 2, alça biliopancreática de $50 \mathrm{~cm}$ e alça alimentar de $150 \mathrm{~cm}$ e grupo 3, alça biliopancreática de $100 \mathrm{~cm}$ e alça alimentar de $150 \mathrm{~cm}$. Foram avaliados os parâmetros que compõem a síndrome metabólica. Resultados: Incluíram-se 63 pacientes, com média de idade de $44.7 \pm 9.4$ anos. Todos eram diabéticos, 62 (98.4\%) hipertensos e 51 (82.2\%) dislipidêmicos. Os três grupos eram homogêneos em relação às variáveis estudadas. Em 24 meses houve remissão da hipertensão arterial sistêmica em $65 \%$ do grupo $1,62.5 \%$ no grupo 2 e $68.4 \%$ no grupo 3 . A remissão do diabete melito tipo 2 ocorreu em $85 \%$ dos pacientes do grupo $1,83 \%$ no grupo 2 , e $84 \%$ no grupo 3 . Não houve diferença estatística na porcentagem de perda do excesso de peso entre os grupos e as medidas da cintura abdominal reduziram de forma homogênea em todos os grupos. A dimensão das alças também não influenciou na melhora da dislipidemia. Conclusão: A variação da dimensão das alças intestinais não influenciou na melhora da síndrome metabólica neste grupo de pacientes.

\section{INTRODUCTION}

(cc) BY This is an open-acces article distributed under the terms of the Creative Commons Attribution License.
$\mathrm{T}$ he definition of better treatment for patients with morbid obesity and/ or metabolic syndrome is a great challenge for bariatric surgeons and clinical investigators. The goal sought by all is to perform a safe and effective procedure, with the lowest rate of complications in the short term as well as long term.

In addition to the various types of surgery for the treatment of these patients, the existing variations within each technique are diverse. Gastric bypass is one of the most utilized surgeries in the world for the treatment of these patients, but the literature still lacks in the definition of the ideal sizes of intestinal loops.

Considering that many obese patients with indication for bariatric surgery are diabetics and have metabolic syndrome and that the surgical techniques with longer intestinal diversions are potentially more deleterious in the uptake of nutrients ${ }^{6}$ we carried out a study to evaluate the metabolic outcomes of these patients submitted to gastric bypass with alimentary and biliopancreatic loops of different sizes. 
METHODS

The project was approved by the Scientific Committee and the Committee of Ethics and Research of the institution (\#11/05596).

Was conducted a retrospective cohort study in obese patients (BMI $\geq 35 \mathrm{~kg} / \mathrm{m}^{2}$ ) diabetics with metabolic syndrome submitted to gastric bypass in a tertiary referral center for the treatment of such patients. The study included obese patients meeting the criteria of diabetes and metabolic syndrome defined by the International Diabetes Federation $(\text { IDF })^{30}$, who had a minimum follow-up of two years. Regular physical activity practitioners were excluded (150 min/ week), those who had complications (fistula, internal hernia, intestinal obstruction) or requiring re-intervention, those who underwent cosmetic surgery or reconstructive abdomen, malignancy history (before or after the operation) and the user of chronic corticosteroids were also excluded.

The variables were measured in the preoperative period and following postoperative times: 3, 6, 12 and 24 months. The data collected were anthropometric measurements, blood pressure levels and the results of laboratory tests. Also identified were the patients who continued using medications in the postoperative period (antihypertensives, oral antidiabetics and/or insulin and antilipemics). The anthropometric data evaluated were weight, height and waist circumference. The serum laboratory tests evaluated were fasting glycemia, total cholesterol, high-density lipoprotein cholesterol (HDL-C) and triglycerides.

The criteria utilized for the identification of patients with metabolic syndrome were based on the classification of the IDF. The waist circumference cutoff was $\geq 90 \mathrm{~cm}$ in men and $\geq 80 \mathrm{~cm}$ in women. Patients were considered hypertensive if systolic (SBP) and diastolic (DBP) blood pressure was $\geq 130 / 85 \mathrm{mmHg}$ or if using antihypertensive medication. Patients were considered dyslipidemic if serum triglycerides $\geq 150 \mathrm{mg} / \mathrm{dl}$ and/or HDL-C $<50 \mathrm{mg} / \mathrm{dl}$ in women and $<40 \mathrm{mg} / \mathrm{dl}$ in men, or if using antilipemic medication. All patients in the sample were diabetics according to the criteria of the American Association of Diabetes (ADA) ${ }^{18}$.

The patients were divided into three groups according to the size of intestinal loops: group 1, biliopancreatic loop of $50 \mathrm{~cm}$ and alimentary loop of $100 \mathrm{~cm}$; group 2 biliopancreatic loop of $50 \mathrm{~cm}$ and alimentary loop of $150 \mathrm{~cm}$; and group 3, biliopancreatic loop of $100 \mathrm{~cm}$ and alimentary loop of $150 \mathrm{~cm}$.

\section{Statistical analysis}

The quantitative variables were expressed as means and standard deviations when their distribution was symmetric and compared between the groups by analysis of variance (ANOVA). These variables were compared within groups by the Student t-test for paired samples. The differences in the variation of the parameters over time between the groups were evaluated utilizing ANOVA for repeated measurements. The categorical variables were expressed as frequencies and percentages and compared by the chi-square test. In all cases, differences were considered significant if $p \leq 0.05$.

RESULTS

Sixty-three patients were evaluated, where 48 (76\%) were females. The mean age was $44.7 \pm 9.4$ years. All patients were diabetics, with 62 (98.4\%) being hypertensive and 51 (82.2\%) dyslipidemic (Table 1). The results obtained in each assessment are presented in Table 2.
TABLE 1 - Characteristics of sample

\begin{tabular}{|c|c|c|c|c|}
\hline & $\begin{array}{c}\text { Group 1 } \\
(\mathrm{n}=20)\end{array}$ & $\begin{array}{c}\text { Group 2 } \\
(\mathrm{n}=24)\end{array}$ & $\begin{array}{c}\text { Group 3 } \\
(\mathrm{n}=19)\end{array}$ & $\mathrm{p}$ \\
\hline Age (years) & $46.2 \pm 9.8$ & $43.7 \pm 7.7$ & $44.3 \pm 11.2$ & 0.692 \\
\hline Gender, female & $15(75 \%)$ & $18(75 \%)$ & $15(79 \%)$ & 0.945 \\
\hline Weight $(\mathrm{kg})$ & $121.2 \pm 21.9$ & $129.2 \pm 22.3$ & $125.77 \pm 17.3$ & 0.451 \\
\hline BMI* $\left.^{*} \mathrm{~kg} / \mathrm{m} 2\right)$ & $45.9 \pm 7.4$ & $46.8 \pm 6.7$ & $46.9 \pm 5.8$ & 0.877 \\
\hline Waist $(\mathrm{cm})^{*}$ & $129 \pm 17$ & $134 \pm 14$ & $131 \pm 11$ & 0.523 \\
\hline SAH* & $19(95 \%)$ & $24(100 \%)$ & $19(100 \%)$ & 0.335 \\
\hline DM2*** & $20(100 \%)$ & $24(100 \%)$ & $19(100 \%)$ & 1.000 \\
\hline Dyslipidemia & $15(75 \%)$ & $21(87 \%)$ & $15(79 \%)$ & 0.555 \\
\hline
\end{tabular}

${ }^{*} \mathrm{BMI}=\mathrm{kg} / \mathrm{m}^{2}$; $*$ SAH =systemic arterial hypertension; ${ }^{* \star *} \mathrm{DM} 2=$ =type 2 diabetes mellitus

TABLE 2 - Characteristics and results of the groups

\begin{tabular}{|c|c|c|c|c|}
\hline & $\begin{array}{c}\text { Group } 1 \\
\mathrm{~N}=20\end{array}$ & $\begin{array}{c}\text { Group } 2 \\
N=24\end{array}$ & $\begin{array}{c}\text { Group } 3 \\
\mathrm{~N}=19\end{array}$ & $\mathrm{p}^{*}$ \\
\hline $\begin{array}{c}\text { \%Loss of excess weight } \\
3 \text { months } \\
6 \text { months } \\
12 \text { months } \\
24 \text { months } \\
\text { p }\end{array}$ & $\begin{array}{c}40.0 \pm 14.8 \\
60.1 \pm 14.4 \\
75.5 \pm 19.2 \\
80.3 \pm 21.8 \\
<0.001\end{array}$ & $\begin{array}{c}42.6 \pm 12.5 \\
60.0 \pm 14.0 \\
79.3 \pm 15.4 \\
79.9 \pm 19.4 \\
<0.001\end{array}$ & $\begin{array}{c}42.0 \pm 13.9 \\
62.3 \pm 20.8 \\
78.0 \pm 22.8 \\
77.9 \pm 21.6 \\
<0.001\end{array}$ & $\begin{array}{l}0.816 \\
0.880 \\
0.804 \\
0.927\end{array}$ \\
\hline $\begin{array}{c}\text { BMI (kg/m2) } \\
\text { Preop } \\
3 \text { months } \\
6 \text { months } \\
12 \text { months } \\
24 \text { months } \\
\text { p }\end{array}$ & $\begin{array}{c}45.9 \pm 7.4 \\
37.9 \pm 7.7 \\
34.0 \pm 6.4 \\
30.8 \pm 6.1 \\
29.8 \pm 5,6 \\
<0.001\end{array}$ & $\begin{array}{c}46,8 \pm 6,7 \\
37,7 \pm 5,9 \\
34,1 \pm 5,5 \\
30,0 \pm 3,6 \\
29,7 \pm 4,0 \\
<0.001\end{array}$ & $\begin{array}{c}46,9 \pm 5,8 \\
38,2 \pm 5,9 \\
34,0 \pm 6,4 \\
30,5 \pm 5,0 \\
30,5 \pm 5,2 \\
<0.001\end{array}$ & $\begin{array}{l}0.877 \\
0.976 \\
0.997 \\
0.858 \\
0.859\end{array}$ \\
\hline $\begin{array}{l}\text { Waist (cm) } \\
\text { Preop } \\
3 \text { months } \\
6 \text { months } \\
12 \text { months } \\
24 \text { months } \\
\text { p }\end{array}$ & $\begin{array}{l}129 \pm 17 \\
113 \pm 16 \\
105 \pm 14 \\
98 \pm 13 \\
96 \pm 13 \\
<0.001\end{array}$ & $\begin{array}{c}134 \pm 14 \\
119 \pm 14 \\
109 \pm 13 \\
100 \pm 10 \\
100 \pm 11 \\
<0.001\end{array}$ & $\begin{array}{l}131 \pm 11 \\
116 \pm 10 \\
107 \pm 11 \\
100 \pm 12 \\
100 \pm 11 \\
<0.001\end{array}$ & $\begin{array}{l}0.523 \\
0.396 \\
0.550 \\
0.866 \\
0.342\end{array}$ \\
\hline $\begin{array}{l}\text { SBP mean } \\
\text { Preop } \\
3 \text { months } \\
6 \text { months } \\
12 \text { months } \\
24 \text { months } \\
\text { p }\end{array}$ & $\begin{array}{c}145 \pm 22 \\
130 \pm 16 \\
126 \pm 12 \\
124 \pm 16 \\
122 \pm 17 \\
0.001\end{array}$ & $\begin{array}{l}151 \pm 25 \\
124 \pm 15 \\
123 \pm 14 \\
120 \pm 14 \\
121 \pm 13 \\
<0.001\end{array}$ & $\begin{array}{l}146 \pm 25 \\
126 \pm 23 \\
126 \pm 25 \\
125 \pm 18 \\
116 \pm 17 \\
<0.001\end{array}$ & $\begin{array}{l}0.669 \\
0.601 \\
0.769 \\
0.590 \\
0.472\end{array}$ \\
\hline $\begin{array}{l}\text { DBP mean } \\
\text { Preop } \\
3 \text { months } \\
6 \text { months } \\
12 \text { months } \\
24 \text { months } \\
\text { p }\end{array}$ & $\begin{array}{l}92 \pm 10 \\
83 \pm 11 \\
82 \pm 10 \\
78 \pm 8 \\
77 \pm 9 \\
<0.001\end{array}$ & $\begin{array}{c}94 \pm 18 \\
78 \pm 10 \\
77 \pm 10 \\
75 \pm 8 \\
75 \pm 9 \\
<0.001\end{array}$ & $\begin{array}{c}86 \pm 13 \\
78 \pm 11 \\
77 \pm 11 \\
76 \pm 12 \\
71 \pm 10 \\
0.001\end{array}$ & $\begin{array}{l}0.269 \\
0.331 \\
0.344 \\
0.604 \\
0.167\end{array}$ \\
\hline $\begin{array}{l}\text { Triglycerides } \\
\text { Preop } \\
3 \text { months } \\
6 \text { months } \\
12 \text { months } \\
24 \text { months } \\
\text { P }\end{array}$ & $\begin{array}{c}162 \pm 68 \\
136 \pm 76 \\
125 \pm 66 \\
111 \pm 64 \\
97 \pm 41 \\
<0.001\end{array}$ & $\begin{array}{c}205 \pm 112 \\
144 \pm 75 \\
129 \pm 66 \\
109 \pm 48 \\
98 \pm 53 \\
<0.001\end{array}$ & $\begin{array}{c}178 \pm 63 \\
146 \pm 55 \\
127 \pm 56 \\
109 \pm 51 \\
98 \pm 38 \\
0.001\end{array}$ & $\begin{array}{l}0.272 \\
0.908 \\
0.980 \\
0.990 \\
0.998\end{array}$ \\
\hline $\begin{array}{c}\text { HDL } \\
\text { Preop } \\
3 \text { months } \\
6 \text { months } \\
12 \text { months } \\
24 \text { months } \\
\text { p }\end{array}$ & $\begin{array}{c}45 \pm 10 \\
41 \pm 7 \\
45 \pm 11 \\
53 \pm 12 \\
53 \pm 13 \\
0.026\end{array}$ & $\begin{array}{c}42 \pm 8 \\
40 \pm 8 \\
44 \pm 8 \\
47 \pm 8 \\
50 \pm 11 \\
0.002\end{array}$ & $\begin{array}{c}44 \pm 12 \\
41 \pm 9 \\
43 \pm 11 \\
53 \pm 14 \\
58 \pm 14 \\
0.01\end{array}$ & $\begin{array}{l}0.653 \\
0.974 \\
0.705 \\
0.149 \\
0.169\end{array}$ \\
\hline $\begin{array}{c}\text { Fasting glycemia } \\
\text { Preop } \\
3 \text { months } \\
6 \text { months } \\
12 \text { months } \\
24 \text { months } \\
\text { p }\end{array}$ & $\begin{array}{c}162 \pm 63 \\
105 \pm 25 \\
97 \pm 21 \\
92 \pm 14 \\
89 \pm 11 \\
<0.001\end{array}$ & $\begin{array}{c}174 \pm 52 \\
103 \pm 19 \\
94 \pm 10 \\
92 \pm 12 \\
87 \pm 8 \\
0.01\end{array}$ & $\begin{array}{c}159 \pm 40 \\
106 \pm 28 \\
90 \pm 11 \\
90 \pm 25 \\
86 \pm 13 \\
0.01\end{array}$ & $\begin{array}{l}0.588 \\
0.902 \\
0.372 \\
0.936 \\
0.550\end{array}$ \\
\hline
\end{tabular}




\section{Loss of excess weight, BMI}

The percent loss of excess weight (\%LEW) is presented in Table 2, showing that there was no significant difference between the three groups, $p>0.05$. The patients of the three groups showed similar results with respect to $\mathrm{BMI}$ at all times evaluated, $p<0.001$. Figure 1 displays the mean \%LEW for the three groups at times 3, 6, 12 and 24 months.

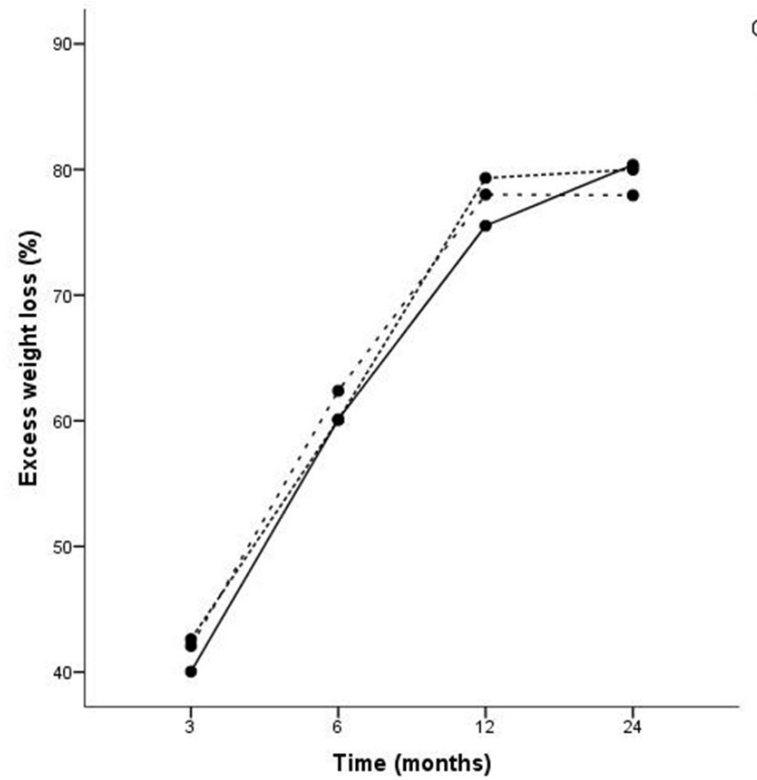

FIGURE 1 - Mean loss of excess weight (\%) in groups 1, 2 and 3 at 3, 6, 12 and 24 months

\section{Waist circumference}

Waist measurements decreased in a homogeneous way in all groups evaluated. Despite a statistically significant reduction $(p<0.001)$ in relation to the data before surgery, only $3 \%(n=2)$ attained measurements below the criteria suggested by the IDF. In group $1,10 \%(n=2)$ reached the criteria recommended by the IDF, which was not observed by any patient in groups 2 and 3. There was no statistical difference with respect to waist measurement between the three groups at any moment evaluated, $\mathrm{p}>0.05$.

\section{Systemic arterial hypertension (SAH)}

In the evaluation of arterial hypertension, $63.1 \%$ of patients in group 1 had controlled blood pressure at 24 months, while $47.3 \%$ showed control at three months, without medication. In group 2, $62.5 \%$ of hypertensives showed controlled SAH at 24 months without medication, but $20 \%$ still had uncontrolled $\mathrm{SAH}$ at this time, even with the use of antihypertensive drugs. In this group, $37.5 \%$ of patients showed control of SAH by the third month. In group 3,68.4\% had controlled SAH at 24 months, where $42.1 \%$ achieved this control already by the third month after surgery. There was no statistical difference with respect to resolution of SAH between the three groups at any moment evaluated, $\mathrm{p}>0.05$.

\section{Triglycerides}

The reduction in triglyceride levels was similar in the three groups. At 12 months, there was a decrease in triglycerides of $39 \%$, and at 24 months, a decrease of $46 \%$. Triglycerides were decreased and remained below $150 \mathrm{mg} / \mathrm{dL}$ in $73 \%$ of all patients, starting at 12 months (group 1: 80\%; group 2: 64.2\%; group 3: 76.9\%), where levels were stable for up to 24 months. In group 1, mean reduction in triglycerides at 24 months was $65.5 \mathrm{mg} / \mathrm{dl}$, whereas $106.6 \mathrm{mg} / \mathrm{dl}$ in group 2 and $79.9 \mathrm{mg} / \mathrm{dl}$ in group 3. There was no statistical difference with regard to the measurement of serum between the three groups at any moment evaluated, $\mathrm{p}>0.05$.
HDL

In group 1, 86.6\% of the dyslipidemic patients showed a serum HDL-C level lower than the reference value of the IDF; in groups 2 and 3, the proportions were 79.1 and 60\%, respectively. At three months, there was a reduction in $\mathrm{HDL}-\mathrm{C}$ levels in the three groups, followed by an elevation in the next periods up to 24 months. Despite a discrete reduction in HDL-C in the period of 12 to 24 months in group 1, the mean HDL-C level remained about $53 \mathrm{mg} / \mathrm{dl}$. The mean increase in HDL-C for the three groups was $7.6 \mathrm{mg} / \mathrm{dl}$ at 24 months. There was no statistical difference with respect to serum $\mathrm{HDL}-\mathrm{C}$ between the three groups at any moment evaluated, $p>0.05$.

\section{DM2}

In group $1,85 \%$ of patients had DM2 controlled without medication already in the third month after surgery. After 24 months, only one patient needed medication to control DM2. In group 2,83\% of patients had DM2 controlled without medication in the third month after surgery. At 24 months, only one of the patients needed an oral hypoglycemic agent to control DM2. In group 3, 84\% controlled DM2 by the third month, remaining so on the $24^{\text {th }}$ month. There was no statistical difference with respect to resolution of DM2 between the three groups at any moment evaluated $(p>0.05)$. Figure 2 shows the mean fasting glycemia $(\mathrm{mg} / \mathrm{dl})$ at the different evaluation times: in the preoperative period and at 3, 6, 12 and 24 months.

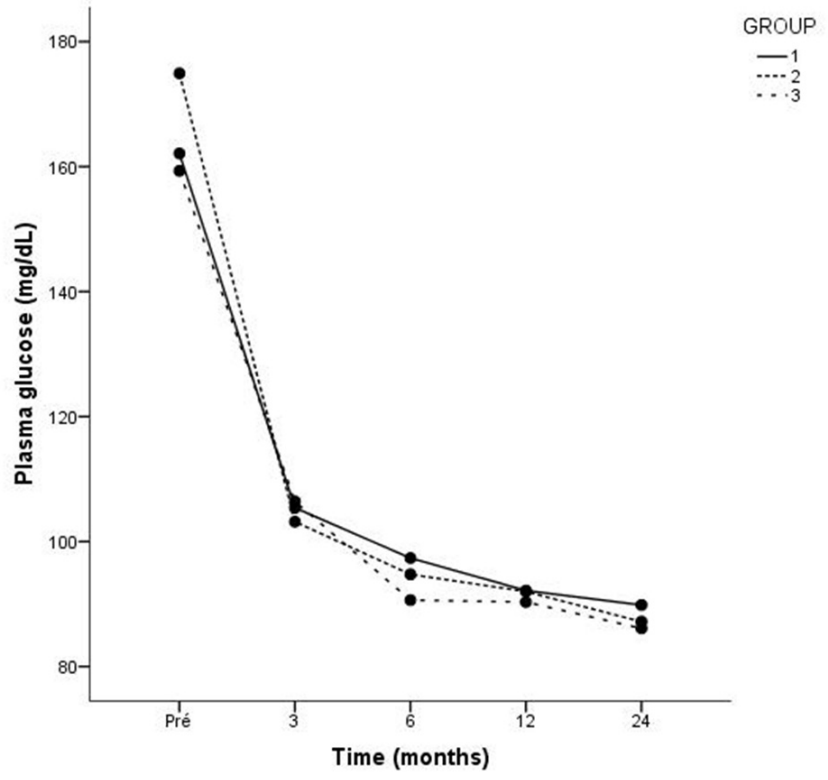

FIGURE 2 - Mean fasting glycemia levels $(\mathrm{mg} / \mathrm{dl})$ in groups 1,2 and 3 in preoperative period and at 3, 6, 12 and 24 months.

\section{DISCUSSION}

In this study, was observed a curve for \%LEW similar to those seen in the literature ${ }^{5,11,24,25}$ and also that the different sizes of intestinal loops did not influence this variable. Two retrospective studies by Christou ${ }^{6}$ and Feng ${ }^{12}$ found no statistical difference in relation to weight loss and \%LEW in a follow-up of 60 months and 12 months, respectively, when comparing different sizes of intestinal loops. A prospective study by Sarhan et al. ${ }^{25}$ also showed no statistical difference in loss of excess weight and in weight regain in a follow-up of 24 months in patients with BMI $>50 \mathrm{~kg} / \mathrm{m}^{28}$. There are three randomized studies ${ }^{5,16,24}$ with similar results as this one. Choban ${ }^{5}$ evaluated the effect of the size of the alimentary loop in 128 patients. There was no statistically difference in 24 and 36 months. Pinheiro ${ }^{24}$ noted that the loss of excess weight in patients with a BMI $\geq 50 \mathrm{~kg} / \mathrm{m}^{2}$ was faster 
in the group with the highest intestinal loop, but was similar in the groups evaluated in 48 months. Inabnet ${ }^{16}$ also showed no statistically difference in weight loss and \%EWL in patients with intestinal loops of different sizes in 24 months. However, Brolin $^{3}$ in their prospective randomized study found statistically significant weight loss in the long bypass in 24 and 36 months $(p \leq 0.02)$. Ciovica ${ }^{7}$ also showed statistically difference in mean $\mathrm{BMI}$ and the final average \%EWL in greater alimentary loop, suggesting that alimentary loop should be larger than $100 \mathrm{~cm}$

\section{Waist circumference}

In this study, there was a decrease in waist circumference in the thre groups, and there was no statistically significant difference over time in relation to size of the intestinal loops. However, the mean waist circumference stayed above the values recommended by the IDF in all the periods evaluated. It should be pointed out that no patient was submitted to aesthetic or reparatory surgery in the abdomen and that part of this measurement could probably be attributed to lipodystrophy and not to visceral adiposity. Despite being one of the criteria of the IDF, waist circumference is an indirect inference of visceral adiposity and does not differentiate lean mass from adipose tissue and nor does it evaluate excess skin and subcutaneous tissue ${ }^{17}$.

Our results are similar to those found in other studies ${ }^{17,23}$, although there was a difference in size of intestinal loops and time of follow-up. In the study of Inge ${ }^{17}$ (biliopancreatic loop $10-15 \mathrm{~cm}$ and alimentary loop $100-150 \mathrm{~cm}$ ) there was a reduction in waist circumference of $144.5 \pm 8.7 \mathrm{~cm}$ to $107.4 \pm 8.4 \mathrm{~cm}$ in 12 months. In a randomizad study ${ }^{23}$ (biliopancreatic loop $30 \mathrm{~cm}$ and alimentary loop $75 \mathrm{~cm}$ ) there was an average reduction in waist circumference of nearly $30 \mathrm{~cm}$ in 12 months.

\section{Blood pressure}

Our results showed an early reduction in blood pressure. Evaluating all patients, there was an improvement in blood pressure in $91.8 \%$ of patients, although $35.5 \%(n=22)$ continued to use antihypertensives, and a resolution of $67.2 \% \mathrm{SAH}$, at 24 months. Similar results are found in some studies ${ }^{1,18,23}$ with similar-sized intestinal loops as utilized in this research, but there are differences in relation to time of follow-up. In some studies, the sizes of the intestinal loops are not specified ${ }^{16-19}$, but the results are similar to those of our study, such as in the meta-analysis of Buchwald ${ }^{4}$ with a resolution of arterial pressure of $62 \%$.

Fernstrom ${ }^{13}$ (biliopancreatic loop of $50 \mathrm{~cm}$ and alimentary loop $150-250 \mathrm{~cm}$ ) had a resolution of $50 \%$ of the pressure at 18 months. Her assessment was not stratified by intestinal loop size. Ahmed ${ }^{1}$ (biliopancreatic loop $30 \mathrm{~cm}$ and alimentary loop $150 \mathrm{~cm}$ ) obtained better results with resolution of hypertension of $88 \%$ in 12 months, but were not accounted patients lost follow-up. Dallal ${ }^{8}$ (biliopancreatic loop $40 \mathrm{~cm}$ and alimentary loop $75-150 \mathrm{~cm}$ ) obtained from the pressure resolution $44.2 \%$ in 12 months. Other studies ${ }^{15,29}$ evaluated only the size of the alimentary loop, with results also similar to those presented here.

\section{Dyslipidemia}

Although $\mathrm{HDL}-\mathrm{C}$ decreased in the first three months, there was improvement in dyslipidemia in the three groups evaluated in our study. There was a greater reduction in triglycerides in the first three months, in the three groups, and an elevation in HDL-C after this period. Probably the worsening of HDL-C was related to the restricted diet on which patients were kept in the initial postoperative period, and this was also described in other studies ${ }^{19,21}$.

Gastric bypass has been shown to be effective in improving the lipid profile as evidenced in the SOS study ${ }^{28}$, where remission of hypertriglyceridemia occurred in $62 \%$ of patients at 24 months and normalization of HDL-C levels in $76 \%$. There are few studies comparing the size of intestinal loops with lipid profile. Studies with a variation in biliopancreatic loop of 50-75 $\mathrm{cm}$ and alimentary loop of 75-250 cm have reported similar results as ours ${ }^{8,24}$, although with variation in time of follow-up. This favorable result is also identified in studies describing only the sizes of the alimentary loop (variation of 75-250 cm) ${ }^{14,21}$. The improvement of the lipid profile seems to maintain longterm. In the study of Jamal ${ }^{19}$ with six-year follow-up, in $76 \%$ of patients there was a reduction of triglycerides to the desired levels in six months and remained until the end of the study period. There was also an increase in HDL. These results are similar to Brolin² that also demonstrated the permanence of satisfactory result in five years even with regained weight or insufficient weight loss

\section{Diabetes}

Hyperglycemia and diabetes are associated with obesity, but improvement in glycemic levels occurs soon after the surgical procedure before a significant reduction in weight $\mathrm{t}^{9,10}$. In our study, remission of diabetes was seen in $92.0 \%$ at 24 months, where in the first three months, the remission rate was $82.5 \%$, and the mean $\mathrm{BMI}$ was $37.9 \pm 0.2$ in this period. This result is similar to that of other studies ${ }^{4,22}$ and reinforces the action of the incretin phenomenon in glycemic control. There are few papers $20,22,24,26,29$ assessing the effect of the size of the bowel gastric bypass in relation to diabetes. There is evidence of improvement in diabetes or remission of the disease in various high-impact publications ${ }^{4,28}$. In the meta-analysis of Buchwald ${ }^{4}$ involving 136 studies and more than 22,000 patients, remission of diabetes was $83.7 \%$. The multicenter study SOS in a follow-up of 10 years described a remission rate of $72 \%{ }^{27,28}$. Some relate the size of the bowel with the $\mathrm{DM} 2^{24,26,29}$. When we compared the studies with a variation of biliopancreatic loop of $30-75 \mathrm{~cm}$ and a variation of alimentary loop of 75-200 $\mathrm{cm}^{26}$, was observed remission in $42-87 \%$ in the period of $12-18$ months and a remission rate of $62-87 \%$ in the period of 24 months. In some studies it was observed remission of DM2 long term ${ }^{29}$ associated with biliopancreatic loop 40-60 $\mathrm{cm}$ and alimentary loop $60-150 \mathrm{~cm}$. The remission in $5-7$ years was 86 $\%$ and in 14 years was $91 \%$. Some authors ${ }^{24}$ show difference in control DM2 compared two groups with different sizes of loops (group1, biliopancreatic loop $50 \mathrm{~cm}$ and alimentary 50 cm; group 2, biliopancreatic loop $100 \mathrm{~cm}$ and alimentary 250 $\mathrm{cm})$. The longer intestinal deviations have better control of DM2 $(p<0,05)$.

Our study has some limitations in relation to the assessment of diabetes. Glycosylated hemoglobin was not determimed in the period of three to 24 months because it is not a parameter utilized for the definition of metabolic syndrome, according to the IDF $^{30}$. In our study, was utilized only the variables that define metabolic syndrome. Also, the quantity of medications taken by each patient was not determined, only whether an oral antidiabetic agent and/or insulin was utilized. The time between the diagnosis of diabetes and the surgical procedure is a factor that affects the remission of diabetes, but that was not evaluated in the present study; was demonstrated an improvement in the control of obesity and the comorbidities studied, but contradicting our hypothesis that a surgery with longer intestinal loops would have a more potent effect, we did not see a difference in the results of patients in the three groups evaluated. Despite the small number of patients, the samples were homogeneous and the patients were evaluated in a systematic way by the same team, and the methods of measurement were identical among the three groups.

\section{CONCLUSION}

Variation in the size of the bowel does not seem to influence the improvement of metabolic syndrome in patients undergoing gastric bypass. 
REFERENCES

1. Ahmed AR, Rickards G, Coniglio D, Xia Y, Johnson J, Boss T, et al. Laparoscopic Roux-en-Y Gastric Bypass and Its Early Effect on Blood Pressure. Obesity Surgery. 2008;19(7):845-9.

2. Brolin RE, Bradley LJ, Wilson AC, Cody RP. Lipid risk profile and weight stability after gastric restrictive operations for morbid obesity. Journal of Gastrointestinal Surgery. 2000;4(5):464-9.

3. Brolin RE, KenlerHA, Gorman JH,CodyRP.Long-limbgastric bypassinthe superobese-Aprospectiverandomizedstudy.AnnSurg.1992;215(4):387-95.

4. BuchwaldH.BariatricSurgery:ASystematicReviewandMeta-analysis.JAMA The Journal of the American Medical Association 2004:292(14):1724-37.

5. Choban PS, Flancbaum L. The Effect of Roux Limb Lengths on Outcome after Roux-en-Y Gastric Bypass: A Prospective, Randomized Clinical Trial. Obesity Surgery. 2002;12:540-5.

6. Christou NV, Look D, MacLean LD. Weight Gain After Short- and Long Limb Gastric Bypass in Patients Followed for Longer Than 10 Years. Annals of Surgery. 2006;244(5):734-40.

7. Ciovica R, Takata M, Vittinghoff E, Lin F, Posselt AM, Rabl C, et al. The Impact of Roux Limb Length on Weight Loss After Gastric Bypass. Obesity Surgery. 2007;18(1):5-10.

8. Dallal RM, Hatalski A, Trang A, Chernoff A. Longitudinal analysis of cardiovascular parameters after gastric bypass surgery. Surgery for Obesity and Related Diseases. 2012;8(6):703-9.

9. Danaei G, Finucane MM, Lu Y, Singh GM, Cowan MJ, Paciorek CJ, et al. National, regional, and global trends in fasting plasma glucose and diabetes prevalencesince 1980:systematicanalysis ofhealthexamination surveys and epidemiological studies with 370 country-years and $2 \cdot 7$ million participants. The Lancet. 2011;378(9785):31-40.

10. de Oliveira LF, Tisott CG, Silvano DM, Campos CM, do Nascimento RR Glycemic Behavior in 48 Hours Postoperative Period of Patients with Type 2 Diabetes Mellitus and Non Diabetic Submitted to Bariatric Surgery. Arquivos brasileiros de cirurgia digestiva : $A B C D=$ Brazilian archives of digestive surgery. 2015;28 Suppl 1:26-30.

11. dos Santos TD, Burgos MG, de Lemos Mda C, Cabral PC. Clinical and Nutritional Aspects in Obese Women during the First Year after RouxEn-Y Gastric Bypass. Arquivos brasileiros de cirurgia digestiva : $A B C D=$ Brazilian archives of digestive surgery. 2015;28 Suppl 1:56-60.

12. Feng JJ, Gagner M, Pomp A, Korgaonkar NM, Jacob BP, Chu CA, et al. Effect of standard vs extended Roux limb length on weight loss outcomes after laparoscopic Roux-en-Y gastric bypass. Surgical Endoscopy. 2003:17(7):1055-60

13. Fernstrom JD, Courcoulas AP, Houck PR, Fernstrom MH. Long-term changes in blood pressure in extremely obese patients who have undergone bariatric surgery. Arch Surg. 2006;141:276-83.

14. Garcia-Marirrodriga I, Amaya-Romero C, Ruiz-Diaz GP, Fernandez S, Ballesta-Lopez C, Pou JM, et al. Evolution of lipid profiles after bariatric surgery. Obes Surg. 2012;22(4):609-16.
15. Hinojosa MW, Varela JE, Smith BR, Che F, Nguyen NT. Resolution of systemic hypertension after laparoscopic gastric bypass. J Gastrointest Surg. 2009;13(4):793-7.

16. Inabnet WB, Quinn T, Gagner M, Urban M, Pomp A. Laparoscopic Rouxen-Ygastric bypassin patientswith BMI50:A prospectiverandomized trial comparing short and long limb lengths. Obesity Surgery. 2005;15:51-7.

17. Inge T, Wilson KA, Gamm K, Kirk S, Garcia VF, Daniels SR. Preferential loss of central (trunk) adiposity in adolescents and young adults after laparoscopic gastric bypass. Surgery for Obesity and Related Diseases. 2007;3(2):153-8

18. Inzucchi SE. Diagnosis of Diabetes. New England Journal of Medicine. 2012;367(6):542-50.

19. Jamal M, Wegner R, Heitshusen D, Liao J, Samuel I. Resolution of hyperlipidemia follows surgical weight loss in patients undergoing Roux-en-Y gastric bypass surgery: a 6-year analysis of data. Surgery for Obesity and Related Diseases. 2011;7(4):473-9.

20. Mingrone G, Panunzi S, Gaetano AD, Guidone C, laconelli A, Leccesi L, et al. Bariatric surgery versus conventional medical therapy for type 2 diabetes. N Engl J Med. 2012:1-9.

21. Nguyen NT, Varela E, Sabio A, Tran C-L, Stamos M, Wilson SE. Resolution of Hyperlipidemia after Laparoscopic Roux-en-Y Gastric Bypass. Journal of the American College of Surgeons. 2006;203(1):24-9.

22. Nora M, Guimarães M, Almeida R, Martins P, Gonçalves G, Freire MJ, et al. Metabolic Laparoscopic Gastric Bypass for Obese Patients with Type 2 Diabetes. Obesity Surgery. 2011;21(11):1643-9.

23. Olbers T, Bjorkman S, Lindroos A, Maleckas A, L??nn L, Sj??str??m L, et al. Body Composition, Dietary Intake, and Energy Expenditure After LaparoscopicRoux-en-YGastricBypassand Laparoscopic VerticalBanded Gastroplasty. Annals of Surgery. 2006;244(5):715-22.

24. Pinheiro JS, Schiavon CA, Pereira PB, Correa JL, Noujaim P, Cohen R Long-long limb Roux-en-Ygastric bypassismore efficaciousintreatment of type 2 diabetes and lipid disorders in super-obese patients. Surgery for Obesity and Related Diseases. 2008;4(4):521-5.

25. Sarhan M, Choi JJ, Sawwaf M, Murtaza G, Getty JLZ, Ahmed L. Is Weight Loss BetterSustained withLong-Limb Gastric BypassintheSuper-Obese? Obesity Surgery. 2011;21(9):1337-43.

26. Schauer PR, Kashyap SR, Wolski K, Brethauer SA, Kirwan JP, Pothier CE, et al. Bariatric surgery versus intensive medical therapy in obese patients with diabetes N Engl J Med. 2012;366(17):1567-76

27. Sjöström L. Bariatric surgery and reduction in morbidity and mortality: experiences from the SOS study. International Journal of Obesity. 2008:32:S93-S7.

28. Sjöström L, Lindroos A-K, Peltonen M, Torgerson J, Bouchard C, Carlsson $B$, et al. Lifestyle, Diabetes, and Cardiovascular Risk Factors 10 Years after BariatricSurgery.NewEngland Journal ofMedicine.2004;351(26):2683-93.

29. Sugerman HJ, Wolfe LG, Sica DA, Clore JN. Diabetes and Hypertension in Severe Obesity. Annals of Surgery. 2003;237(6):751-8.

30. Zimmet P, Magliano D, Matsuzawa Y, Alberti G, Shaw J. The metabolic syndrome: a global public health problem and a new definition. J Atheroscler Thromb. 2005;12(6):295-300. 